\title{
Pengaruh Likuiditas, Pajak,Profitabilitas terhadap Struktur Modal pada Sektor Aneka Industri yang terdaftar di BEI
}

\author{
Evander Paskah Zalukhu \\ Universitas Prima Indonesia \\ evanderpaskah525@gmail.com \\ Ruslina E.Sinambela \\ Universitas Prima Indonesia \\ ruslinasinambela@gmail.com
}

\author{
Pandang Kristian Simarmata \\ Universitas Prima Indonesia \\ pandangk.s22@gmail.com \\ Nurleli Octresia Purba \\ Universitas Prima Indonesia \\ nurlelioctresiapurba@gmail.com
}

\section{Jholant Bringg Luck Amelia Br.Sinaga \\ Universitas Prima Indonesia \\ jho.amelia@gmail.com}

Corresponding Author : Evander Paskah Zalukhu

Submitted: 18 Juli 2020

Accepted: 13 Agustus 2020

Published: 13 Agustus 2020

\begin{abstract}
ABSTRAK
Penelitian ini dilakukan pada perusahaan Sektor Aneka Industri yang terdaftar di Bursa Efek Indonesia dengan tujuan untuk menguji pengaruh Likuiditas, Pajak, dan Profitabilitas Terhadap Struktur Modal. Pendekatan penelitian yang digunakan dalam penelitian adalah pendekatan kuantitatif. Jenis penelitian yang dipakai adalah deskriptif kuantitatif dan sifat penelitian ini adalah bersifat kausal. Metode pengumpulan data yang diperlukan adalah data sekunder pada laporan keuangan. Penentuan sampel penelitian dengan menggunakan metode purposive sampling. Jumlah populasi sejumlah 42 perusahaan sehingga total jumlah sampel yang akan diteliti sebanyak 19 perusahaan sehingga total jumlah sampel yang akan diteliti sebanyak 57 pengamatan $(19 \times 3)$. Teknik analisis data yang digunakan adalah analisis linear berganda. Berdasarkan hasil analisis ditemukan bahwa Likuiditas secara parsial berpengaruh negatif dan signifikan terhadap Struktur Modal, Pajak secara parsial tidak berpengaruh dan tidak signifikan terhadap Struktur Modal, Profitabilitas secara parsial tidak berpengaruh dan tidak signifikan terhadap Struktur Modal. Secara signifikan Likuiditas, Pajak dan Profitabilitas berpengaruh terhadap Struktur Modal.Hasil uji koefisien determinasi diperoleh nilai Adjusted $R$ Square $\left(\mathrm{R}^{2}\right)$ sebesar 0,100 atau sama dengan $10 \%$. Variabel independen berpengaruh terhadap Struktur Modal Pada Perusahaan Sektor Aneka Industri di Bursa Efek Indonesia Periode 2015-2017 sebesar $10 \%$ dan sisanya $90 \%$ dipengaruhi variabel lain seperti Stabilitas Penjualan, Kebijakan Deviden, Struktur Aktiva.
\end{abstract}

Kata Kunci : Likuiditas , Pajak, Profitabilitas,Struktur Modal

This is an Creative Commons License This work is licensed under a
Creative Commons Attribution-NonCommercial 4.0 International
License.




\section{PENDAHULUAN}

Jika dilihat dari kemajuan zaman sekarang yang semakin berkembang dengan baik, setiap perusahaan saling berpacu secara sehat untuk menjaga perusahaannya sebaik mungkin. Pemakaian modal yang kecil tetapi mendapatkan laba yang besar menjadi salah satu tujuan perusahaan. Jadi, setiap perusahaan yang akan didirikan tidak memakai modal sendiri tetapi perusahaan itu juga membutuhkan dana dari para investor atau dana dari pemilik modal.

Perusahaan sektor aneka industri bisa mempengaruhi pendapatan perekonomian negara, yang dimana para investor menginvestasikan uang mereka. Sub sektor industri meliputi sub bidang otomotif dan komponen, sub bidang mesin, dan sub sektor elektronika.

Dilihat dari kreditur, perusahaaan yang mempunyai likuiditas yang banyak tergolong perusahaan yang baik. Jika perusahaan memiliki stok kebijakan kredit perusahaan yang tidak pas mengakibatkan besarnya piutang perusahaan.

Bagi negara pajak menjadi salah satu pendapatan, tetapi pada setiap perusahaan pajak itu pengeluaran yang mengurangi pendapatan perusahaan. Pajak setiap peusahaan tergantung pada laba perusahaan, semakin tinggi pendapatan perusahaan menyebabkan pajak yang harus dibayar perusahaan semakin banyak. Karena hal tersebut banyak perusahaan memanipulasi laporan keuangan mereka demi menghindar dari pajak baik itu secara tidak sehat atau punah.

Laba hal yang sangat penting bagi perusahaan. Bagi pemimpin perusahaan laba menjadi tolak ukur apakah perusahaan yang dipimpinnya berjalan dengan baik. Pada karyawan jika laba yang di peroleh tinggi maka gaji mereka dapat dinaikkan. Dan jika laba setiap perusahaan stabil maka hal tersebut membuat para penanam modal untuk menginvestasikan uang mereka, dan juga perusahaan mampu menjaga kelangsungan usahanya secara efisien.

Tabel Fenomena

\begin{tabular}{|c|c|c|c|c|c|c|}
\hline No & $\begin{array}{c}\text { Nama } \\
\text { Perusahaan }\end{array}$ & $\begin{array}{c}\text { Tahu } \\
\mathrm{n}\end{array}$ & Aktiva Lancar & Pajak Tahunan & Laba & Total Hutang \\
\hline \multirow{3}{*}{1} & \multirow{3}{*}{$\begin{array}{c}(\text { ERTX }) \\
\text { EratexDjajaTb } \\
\text { k }\end{array}$} & 2015 & 370.392 .648 .144 & 13.111 .413 & 73.025 .694 .696 & 497.090 .101 .496 \\
\hline & & 2016 & 289.830 .768 .528 & 8.302 .218 .480 & 21.055 .970 .565 & 440.977 .112 .142 \\
\hline & & 2017 & 379.873 .379 .160 & 399.165 .720 & 23.804.014.362 & 561.138 .062 .280 \\
\hline \multirow{3}{*}{2} & \multirow{3}{*}{$\begin{array}{c}\text { (KBLI) KMI } \\
\text { Wire \& Cable } \\
\text { Tbk }\end{array}$} & 2015 & 961.562 .673 & 34.677 .927 & 115.371 .098 & 524.401 .909 .934 \\
\hline & & 2016 & 1.223 .453 .184 & 51.790 .904 & 334.338 .838 & 550.076 .575 .595 \\
\hline & & 2017 & 1.843 .100 .258 & 69.910 .827 & 238.974 .051 & 1.227.014.231.702 \\
\hline \multirow{3}{*}{3} & \multirow{3}{*}{$\begin{array}{c}\text { (BRAM) Indo } \\
\text { KordsaTbk }\end{array}$} & 2015 & 1.415 .482 .221 .656 & 468.256 .048 .281 & 174.320 .473 .584 & 1.509 .801 .259 .624 \\
\hline & & 2016 & 1.520 .685 .053 .433 & 702.284 .658 .240 & 301.111 .255 .746 & 1.327 .558 .855 .035 \\
\hline & & 2017 & 1.580 .317 .642 .440 & 128.840 .489 .160 & 333.141 .090 .120 & 1.333 .162 .858 .200 \\
\hline
\end{tabular}

Untuk perusahaan (ERTX) Eratex Djaja Tbk, Aktiva Lancar ditahun 20152016 menurun Rp. 80.561.879.616. Pajak Tahunan ditahun 2015-2016 mengalami kenaikan sebesar Rp.
8.289.107.067. Laba ditahun 2015-2016 menurun Rp 51.969.724.131. Total Hutang ditahun 2015-2016 menurun Rp.56.112.989.354.

Untuk perusahaan (BRAM) Indo 
Kordsa Tbk, Aktiva Lancar ditahun 2015-2016 naik sejumlah Rp 261.890.511. Pajak Tahunan ditahun 2015-2016 naik sejumlah $R p$ 17.112.977. Laba ditahun 2015-2016 naik sejumlah $\mathrm{Rp}$ 218.967.740. Total Hutang ditahun 2015-2016 naik sejumlah Rp25.674.665.661.

Untuk perusahaan (KBLI) KMI Wire \& Cable Tbk, Aktiva Lancar ditahun 2015-2016 naik sejumlah $\mathrm{Rp}$ 105.201.831.777. Pajak Tahunan ditahun 2015-2016 naik sejumlah $\mathrm{Rp}$ 234.028.609.959. Laba ditahun 20152016 naik sejumlah $\mathrm{Rp}$ 126.790.782.162. Total Hutang ditahun 2015-2016 naik sejumlah $\mathrm{Rp}$ 817.677.595.411.

Pengambilan keputusan struktur modal mempengaruhi besarnya risiko yang dihadapi para penanam modal dantingginya tingkat pengembalian atau tingkat laba yang diinginkan.

Adapun beberapa penelitian yang dapat membantu keterkaitan struktur modal antara lain :

Peneliti Rahmadianti dan kawankawan yang berjudul "Pengaruh Profitabilitas, Risiko Bisnis, Kepemilikan Manajerial, dan Pajak Terhadap Struktur Modal" mengatakan bahwa pajak berpengaruh signifikan terhadap struktur modal dengan hasil penelitian Pajak berpengaruh terhadap struktur modal (Rahmadianti \& Yuliandi, 2020).

Peneliti Andarsari dan kawankawan yang berjudul "The Effect of Liquidity, Cooperative Size, and Profitability on the Capital Structure Among Koperasi Wanita In Malang" menemukan bahwa hasil penelitiannya likuiditas berpengaruh negatif terhadap struktur modal (Andarsari et al, 2016).

Peneliti Pramana \& Mustanda yang berjudul "Pengaruh profitabilitas dan size terhadap nilai perusahaan dengan CSR sebagai variabel pemoderasi. Penelitian dilakukan pada perusahaan partisipan Indonesia Sustainability Reporting Award yang terdaftar di BEI periode 2010-2013". Hasil penelitian menunjukkan bahwa profitabilitas secara signifikan berpengaruh positif terhadap nilai perusahaan (Pramana \& Mustanda, 2015).

\section{Tinjauan Pustaka \\ 2.1 Pengaruh Likuiditas Terhadap Struktur Modal}

Peneliti Wulandari \& Artini; Amanda menunjukkan bahwa likuiditas suatu perusahaan memiliki pengaruh negatif dan signifikan terhadap struktur modal (Wulandari \& Artini, 2016); (Amanda, Ayu, 2016). Menurut (Fahmi, 2015) dengan indikator :

$$
\text { Curent Ratio }=\frac{\text { Aktiva Lancar }}{\text { Utang Lancar }}
$$

Berdasarkan uraian tersebut, maka hipotesis yang diajukan sebagai berikut:

$\mathrm{H}_{1} \quad$ : Likuiditas berpengaruh negatif dan signifikan terhadap struktur modal.

\subsection{Pengaruh Pajak Terhadap Struktur Modal}

Pajak berpengaruh negatif terhadap struktur modal. Hal ini karena perusahaan tidak berani menggunakan utang yang terlalu besar dalam mendanai aktivitasnya (Toni, 2016).

Semakin besar hutang, maka akan memperbesar biaya bunga yang timbul atas hutang tersebut. Semakin meningkatkanya biaya, maka akan menyebabkan penghasilan kena pajak menjadi semakin kecil $(\mathrm{Ge}, 2013)$ dengan indikator :

$$
\begin{gathered}
\text { Pajak }=\text { PKP } \times \text { Tarif PPh (2) } \\
\text { Berdasarkan uraian tersebut, }
\end{gathered}
$$
maka hipotesis yang diajukan sebagai berikut:

$\mathrm{H}_{2}$ : Pajak berpengaruh negatif terhadap struktur modal. 


\subsection{Pengaruh Profitabilitas Terhadap Struktur Modal}

Perusahaan yang menghasilkan laba yang tinggi akan menggunakan hutang akan relatif kecil yang menunjukkan bahwa profitabilitas berpengaruh terhadap struktur modal $(\mathrm{Ni}$ Komang Ayu \& Ni Luh Putu, 2017) dengan menggunakan perhitungan :

Earning After Interest Tax

$$
R O E=\frac{\text { Equity }}{\text { (3) }}
$$

Berdasarkan uraian tersebut, maka hipotesis yang diajukan sebagai berikut:

$\mathrm{H}_{3} \quad$ : Profitabilitas berpengaruh positif dan signifikan terhadap struktur modal.

\section{Metodologi Penelitian}

\subsection{Jenis Penelitian}

Pendekatan penelitian yang dipakai yaitu pendekatan deskriptif serta metode kuantitatif. Penelitian ini menggunakan data sekunder yang di publikasikan bank (Sugiyono, 2016).

\subsection{Populasi dan Sampel}

Populasi yang digunakan yakni semua perusahaan manufaktur di sektor aneka industri yang tercatat di BEI sejumlah 42 perusahaan yang listing di Bursa Efek Indonesia tahun 2015-2017. Teknik penarikan sampel dengan menggunakan metode purposive sampling (Anwar Sanusi, 2014). Dimana kriteria perusahaan yang dijadikan sampel adalah :

Tabel 1. Kriteria Pengambilan Sampel

\begin{tabular}{|c|c|c|}
\hline No & Kriteria & $\begin{array}{c}\text { Jumlah } \\
\text { Sampel }\end{array}$ \\
\hline 1 & $\begin{array}{l}\text { Perusahaan bidang } \\
\text { aneka industri yang } \\
\text { tercatat pada BEI } \\
\text { periode 2014-2016. }\end{array}$ & 42 \\
\hline 2 & $\begin{array}{l}\text { Perusahaan bidang } \\
\text { aneka industri yang } \\
\text { terdaftar pada BEI }\end{array}$ & \multicolumn{1}{|c|}{} \\
\hline
\end{tabular}

\begin{tabular}{|l|l|c|}
\hline & $\begin{array}{l}\text { yang tidak } \\
\text { menerbitkan } \\
\text { laporan } \\
\text { keuangannya yang } \\
\text { lengkap secara } \\
\text { berurutan tahun } \\
2014-2016 \quad\end{array}$ & \\
\hline 3 & $\begin{array}{l}\text { Perusahaan bidang } \\
\text { aneka industri yang } \\
\text { terdaftar pada BEI } \\
\text { yang Rugi periode } \\
\text { 2014-2016 }\end{array}$ & \\
\hline Tahun periode & 3 \\
\hline Jumlah Sampel (19 x 3) & 57 \\
\hline
\end{tabular}

Sumber : www.idx.co.id

\section{Hasil dan Pembahasan \\ 4.1 Uji Asumsi Klasik}

\section{Uji Normalitas}

Uji normalitas tujuannya mengukur apakah pada model regresi, variabel residual berdistribusi normal (Ghozali, H. I, 2016).

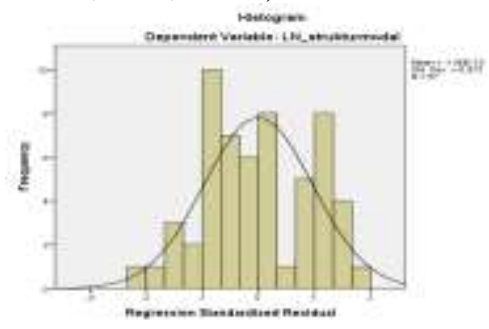

Gambar 1. Grafik Histogram

Dari gambar grafik histogram di atas, memperlihatkan garis kurva cenderung simetri. Jadi bisa disimpulkan datanya berdistribusi normal.

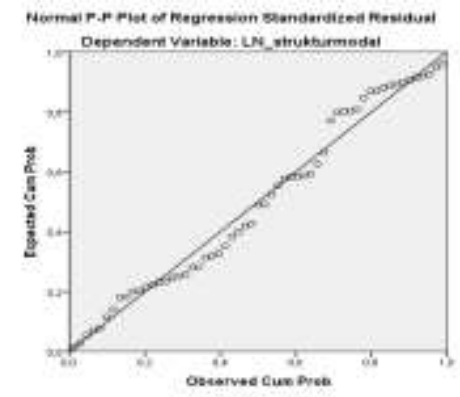




\begin{tabular}{|c|c|c|c|c|c|c|c|c|}
\hline \multicolumn{9}{|c|}{ Coefficients $^{\mathbf{a}}$} \\
\hline & & \multicolumn{2}{|c|}{$\begin{array}{l}\text { Unstandardi } \\
\text { zed } \\
\text { Coefficients }\end{array}$} & $\begin{array}{l}\text { Standard } \\
\text { ized } \\
\text { Coefficie } \\
\text { nts }\end{array}$ & \multirow[b]{2}{*}{$\mathrm{T}$} & \multirow[b]{2}{*}{ Sig. } & \multicolumn{2}{|c|}{$\begin{array}{c}\text { Collinearity } \\
\text { Statistics }\end{array}$} \\
\hline \multicolumn{2}{|c|}{ Model } & B & $\begin{array}{l}\text { Std. } \\
\text { Error }\end{array}$ & Beta & & & $\begin{array}{l}\text { Toler } \\
\text { ance }\end{array}$ & VIF \\
\hline \multirow[t]{4}{*}{1} & (Constant) &, 632 & 1,012 & & 624 &, 535 & & \\
\hline & $\begin{array}{l}\text { LN_likuid } \\
\text { itas }\end{array}$ & , 348 & , 143 &,- 323 & $2,439^{-}$ & ,018 & ,916 & 1,092 \\
\hline & LN_pajak & , 019 & ,040 &,- 064 &,- 459 & ,648 & ,829 & 1,206 \\
\hline & $\begin{array}{l}\text { LN_profit } \\
\text { abilitas }\end{array}$ & ,098 & ,067 & , 196 & 1,470 & , 147 & 901 & 1,110 \\
\hline
\end{tabular}

Gambar 2. Grafik Uji Normalitas P-Plot

Dari gambar di atas menujukkan titiknya mengikuti garis diagonalnya. Maka, disimpulkan datanya berdistribusi normal.

Tabel 3. Uji Kolmogorov-Smirnov Test

One-Sample Kolmogorov-Smirnov Test

\begin{tabular}{|c|c|c|}
\hline & & $\begin{array}{l}\text { Unstandardized } \\
\text { Residual }\end{array}$ \\
\hline $\mathrm{N}$ & & 57 \\
\hline Normal & Mean & ,0000000 \\
\hline Parameters ${ }^{\mathrm{a}, \mathrm{b}}$ & $\begin{array}{l}\text { Std. } \\
\text { Deviatio } \\
\mathrm{n}\end{array}$ & ,70733111 \\
\hline Most Extreme & Absolute & , 103 \\
\hline Differences & Positive &, 080 \\
\hline & Negative &,- 103 \\
\hline Test Statistic & & , 103 \\
\hline Asymp. Sig. (2 & led) & $200^{\mathrm{c}, \mathrm{d}}$ \\
\hline
\end{tabular}

Berdasarkan hasil uji normalitas Kolmogorov Smirnov menunjukkan hasil uji statistik bahwa variabel Likuiditas, Pajak, Profitabilitas dan Struktur Modal telah memenuhi syarat distribusi normal karena nilai signifikan $0,200>0,05$.

\subsection{Uji Multikolinearitas}

Uji multikolonieritas tujuannya mengukur apakah ada korelasi antara variabel bebas menentukan model regresi yang saling berhubungan (Ghozali, H. I, 2016).
Tabel 4. Uji Multikolniearitas

Dari gambar tabel multikolinearitas, nilai tolerance pada variabel likuiditas, pajak, dan profitabilitas lebih besar dari 0,01 sedangkan nilai VIF nya kurang dari 10 sehingga tidak mengalami multikolinearitas.

\subsection{Uji Autokorelasi}

Uji autokorelasi tujuannya untuk mengukur apakah pada model regresinya terdapat hubungan diantara kesalahan pengganggunya pada periode $t$ dengan periode t-1 (Ghozali, H. I, 2016), dengan hasil uji berikut.

Tabel 5. Uji Autokolerasi

\begin{tabular}{|c|c|c|c|c|c|c|c|c|c|c|}
\hline \multicolumn{11}{|c|}{ Model Summary ${ }^{b}$} \\
\hline \multirow[b]{2}{*}{ Model } & \multirow[b]{2}{*}{$\mathrm{R}$} & \multirow[b]{2}{*}{$\begin{array}{l}\mathrm{R} \\
\text { Squa } \\
\text { re }\end{array}$} & \multirow[b]{2}{*}{$\begin{array}{c}\text { Adju } \\
\text { sted } \\
\text { R } \\
\text { Squa } \\
\text { re }\end{array}$} & \multirow[b]{2}{*}{$\begin{array}{l}\text { Std. } \\
\text { Error of } \\
\text { the } \\
\text { Estimate }\end{array}$} & \multicolumn{5}{|c|}{ Change Statistics } & $\begin{array}{c}\text { Durbin } \\
- \\
\text { Watson }\end{array}$ \\
\hline & & & & & $\begin{array}{c}\text { R } \\
\text { Squar } \\
\text { e } \\
\text { Chan } \\
\text { ge }\end{array}$ & $\begin{array}{c}\text { F } \\
\text { Chan } \\
\text { ge }\end{array}$ & df1 & $\begin{array}{c}\mathrm{df} \\
2\end{array}$ & $\begin{array}{l}\text { Sig. } \\
\text { F } \\
\text { Chan } \\
\text { ge }\end{array}$ & \\
\hline 1 & $\begin{array}{r}3 \\
85 \\
\text { a }\end{array}$ &, 148 &, 100 & ,72707 &, 148 & 3,067 & 3 & 53 & ,036 & 1,939 \\
\hline
\end{tabular}

Sumber : Pengolahan SPSS 24

Dari tabel di atas ialah 1.939. Hasil uji Durbin-Watson sebesar 1,939 setelah di hitung diperoleh nilai $\mathrm{dl}=1.4637, \mathrm{du}=1.6845 \mathrm{dan} 4-\mathrm{du}=2.3155$, maka $\mathrm{du}<\mathrm{d}<4$-du $(1.6845<1.939<$ 2.3155) menunjukkan jika tidak terjadi autokorelasi positif ataupun negatif.

\subsection{Uji Heterokedastisitas}

Uji heteroskedastisitas tujuannya untuk mengukur apakah pada model regresi ada ketidaksamaan variance dari residual sebuah pengamatan ke pengataman lainnya (Ghozali, H. I, 2016). 


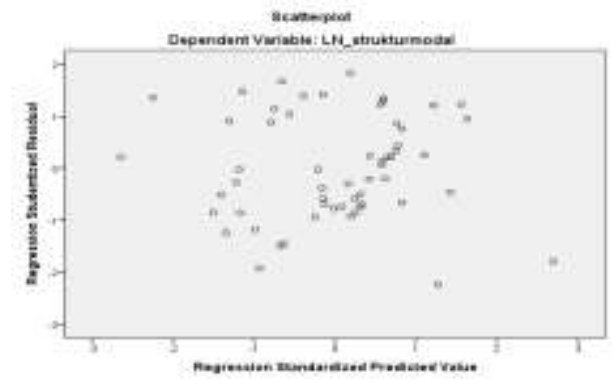

Gambar 3. Uji Heteroskedastisitas Pada gambar di atas terlihat titiknya tersebar dengan acak baik ke atas ataupun ke bawah angka nol (0) dalam sumbu Y. Jadi dari grafik Scatterplot kesimpulannya ialah tidak mengalami Heteroskedastisitas.

Selain itu, dilakukan pendeteksian dengan metode uji gletser sebagai berikut.

Tabel 6. Hasil Uji Gletser (Setelah Transformasi)

\begin{tabular}{|c|c|c|c|c|c|c|}
\hline \multicolumn{7}{|c|}{ Coefficients $^{\mathrm{a}}$} \\
\hline \multirow{2}{*}{\multicolumn{2}{|c|}{ Model }} & \multicolumn{2}{|c|}{$\begin{array}{l}\text { Unstandardize } \\
\text { d Coefficients }\end{array}$} & \multirow{2}{*}{$\begin{array}{l}\text { Standa } \\
\text { rdized } \\
\text { Coeffi } \\
\text { cients }\end{array}$} & \multirow[t]{2}{*}{$\mathrm{T}$} & \multirow[t]{2}{*}{ Sig. } \\
\hline & & B & $\begin{array}{l}\text { Std. } \\
\text { Error }\end{array}$ & & & \\
\hline \multirow[t]{4}{*}{1} & (Constant) & 1,282 &, 526 & & 2,436 & ,018 \\
\hline & $\begin{array}{l}\mathrm{LN} \_ \text {likuidita } \\
\mathrm{S}\end{array}$ & ,075 & ,074 & ,141 & 1,007 & ,318 \\
\hline & LN__Pajak &,- 028 & ,021 &,- 195 & $1,322^{-}$ & , 192 \\
\hline & $\begin{array}{l}\text { LN__Profitabi } \\
\text { litas }\end{array}$ &, 030 & ,035 & ,123 &, 872 & ,387 \\
\hline
\end{tabular}

Pada tabel uji gletser memperlihatkan likuiditas mempunyai nilai signifikan 0,318 , variabel pajak mempunyai nilai signifikannya $\quad 0,192 \quad$ variabel profitabilitas mempunyai nilai signifikan 0.387, maka kesimpulannya tidak mengalami heteroskedastisitas. Karena nilai signifikan variabel likuiditas, pajak dan profitabilitas $>0,05$.

\subsection{Hasil Analisis Data Penelitian}

Pengujian hipotesis yang digunakan dalam penelitian ini menggunakan analisis regresi linear berganda. Model regersi yang dilakukan ialah:

Tabel 7.Persamaan Regresi

\begin{tabular}{|c|c|c|c|c|c|c|c|c|}
\hline \multicolumn{9}{|c|}{ Coefficients $^{\mathrm{a}}$} \\
\hline \multirow{2}{*}{\multicolumn{2}{|c|}{ Model }} & \multicolumn{2}{|c|}{$\begin{array}{l}\text { Unstandardized } \\
\text { Coefficients }\end{array}$} & \multirow{2}{*}{$\begin{array}{c}\text { Standar } \\
\text { dized } \\
\text { Coeffic } \\
\text { ients } \\
\text { Beta }\end{array}$} & \multirow[b]{2}{*}{$\mathrm{T}$} & \multirow[b]{2}{*}{ Sig. } & \multicolumn{2}{|c|}{$\begin{array}{c}\text { Collinearity } \\
\text { Statistics } \\
\end{array}$} \\
\hline & & B & $\begin{array}{c}\text { Std. } \\
\text { Error }\end{array}$ & & & & $\begin{array}{c}\text { Tolera } \\
\text { nce }\end{array}$ & VIF \\
\hline \multirow[t]{4}{*}{1} & $\begin{array}{l}\text { (Consta } \\
\text { nt) }\end{array}$ & ,632 & 1,012 & & ,624 &, 535 & & \\
\hline & $\begin{array}{l}\text { LN_liku } \\
\text { iditas }\end{array}$ &,- 348 &, 143 &,- 323 & $-2,439$ & ,018 & ,916 & 1,092 \\
\hline & $\begin{array}{l}\text { LN_paj } \\
\text { ak }\end{array}$ &,- 019 &, 040 &,- 064 &,- 459 & ,648 & ,829 & 1,206 \\
\hline & $\begin{array}{l}\text { LN_pro } \\
\text { fitabilita } \\
\mathrm{s}\end{array}$ & ,098 & ,067 & , 196 & 1,470 & , 147 & ,901 & 1,110 \\
\hline
\end{tabular}

Sumber : Pengolahan SPSS 24

Dari hasil tersebut, maka persamaan regresinya adalah :

\section{$\mathrm{DER}=0.632-0.348 \mathrm{CR}+0.019$ PAJAK+ 0.098 ROE}

Berdasarkan persamaan di atas dapat diartikan :

1. Nilai konstanta sebesar 63\%. Maksudnya variabel likuiditas (X1), pajak, profitabilitas dianggap konstan. Maka struktur modal (Y) untuk Perusahaan Bidang Aneka Industri di BEI tahun 2015-2017 adalah sebesar $63 \%$.

2. Nilai koefisien likuiditas (X1) ialah 34\%. Ini memperlihatkan bahwa setiap penurunan likuiditas sekali jadi Struktur modalnya akan berkurang $34 \%$.

3. Nilai koefisien pajak (X2) adalah 1\%. Ini memperlihatkan jika masing-masing penurunan pajak sekali jadi Struktur Modal akan turun $1 \%$.

4. Nilai koefisien profitabilitas (X3) adalah $9 \%$. Ini memperlihatkan jika 
tiap kenaikan profitabilitas sekali jadi Struktur Modal mengalami kenaikan $9 \%$.

\subsection{Koefisien Determinasi $\left(R^{2}\right)$}

Jika nilai $\mathrm{R}^{2}$ sedikit berarti kesanggupan variabel independen untuk menggambarkan jenis variabe dependennya teramat minim (Ghozali, $\mathrm{H}$ I, 2016). Hasil uji $\mathrm{R}^{2}$ yakni sebaga berikut.

Tabel 8.Uji Koefisien Determinasi

\begin{tabular}{|l|c|c|c|c|c|}
\hline \multicolumn{5}{|c|}{ Model Summary $^{\mathbf{b}}$} \\
\hline $\begin{array}{l}\text { Mod } \\
\text { el }\end{array}$ & $\mathrm{R}$ & $\begin{array}{c}\text { R } \\
\text { Squar }\end{array}$ & $\begin{array}{c}\text { Adjus } \\
\text { ted R } \\
\text { Squar } \\
\text { e }\end{array}$ & $\begin{array}{c}\text { Std. Error } \\
\text { of the } \\
\text { Estimate }\end{array}$ & $\begin{array}{c}\text { Durbin- } \\
\text { Watson }\end{array}$ \\
\hline 1 &, $385^{\mathrm{a}}$ &, 148 &, 100 &, 72707 & 1,939 \\
\hline \multicolumn{5}{|c|}{ Sumber : Olahan Data SPSS 24 }
\end{tabular}

Dari tabel di atas, diperoleh nilai adjusted $R$ square $\left(\mathrm{R}^{2}\right)$ 0,100 ataupun sama dengan $10 \%$. Variabel independen mempengaruhi Struktur Modal untuk Perusahaan Bidang Aneka Industri Di BEI Tahun 2015-2017 sebesar $10 \%$ dan sisanya $90 \%$ yang mempengaruhi ialah variabel lainnya seperti Stabilitas Penjualan, Kebijakan Deviden, Struktur Aktiva.

\subsection{Pengujian Hipotesis Secara Simultan (Uji F)}

Tabel 10. Uji t

\begin{tabular}{|c|c|c|c|c|c|c|c|c|}
\hline \multicolumn{9}{|c|}{ Coefficients $^{\mathrm{a}}$} \\
\hline \multirow{2}{*}{\multicolumn{2}{|c|}{ Model }} & \multicolumn{2}{|c|}{$\begin{array}{c}\text { Unstandardized } \\
\text { Coefficients }\end{array}$} & \multirow{2}{*}{\begin{tabular}{c|}
$\begin{array}{c}\text { Standardized } \\
\text { Coefficients }\end{array}$ \\
Beta
\end{tabular}} & \multirow[b]{2}{*}{$\mathrm{T}$} & \multirow[b]{2}{*}{ Sig. } & \multicolumn{2}{|c|}{$\begin{array}{l}\text { Collinearity } \\
\text { Statistics }\end{array}$} \\
\hline & & $\mathrm{B}$ & Std. Error & & & & Tolerance & VIF \\
\hline & (Constant) & 632 & 1,012 & & ,624 &, 535 & & \\
\hline & LN_likuiditas &,- 348 & ,143 &,- 323 & $-2,439$ & ,018 & 916 & 1,092 \\
\hline & LN_pajak &,- 019 & 040 &,- 064 &,- 459 & ,648 & ,829 & 1,206 \\
\hline & LN_profitabilitas &, 098 & 067 & ,196 & 1,470 &, 147 & ,901 & 1,110 \\
\hline
\end{tabular}

Sumber : Pengolahan Data SPSS 24
Uji statistik F awalnya memperlihatkan apakah seluruh variabel bebas yang diikutkanpada model memiliki efek yang serupa dengan variabel dependennya (Ghozali, H. I, 2016). Dengan hasil uji yaitu :

Tabel 9. Uji F

\begin{tabular}{|c|c|c|c|c|c|c|}
\hline \multicolumn{7}{|c|}{ ANOVA $^{a}$} \\
\hline \multicolumn{2}{|c|}{ Model } & $\begin{array}{c}\text { Sum of } \\
\text { Squares }\end{array}$ & Df & $\begin{array}{l}\text { Mean } \\
\text { Square }\end{array}$ & $\mathrm{F}$ & Sig. \\
\hline 1 & $\begin{array}{l}\text { Regressio } \\
n\end{array}$ & 4,863 & 3 & 1,621 & 3,067 &, $036^{\mathrm{b}}$ \\
\hline & Residual & 28,018 & 53 &, 529 & & \\
\hline & Total & 32,881 & 56 & & & \\
\hline
\end{tabular}

Tabel di atas memperlihatkan nilai $F_{\text {hitung }}$ sebesar 3,067 dimana nilai signifikannya 0,036 , sementara $F_{\text {tabel }} 2,78$ jadi dapat disimpulkan $\mathrm{F}_{\text {hitung }}>\mathrm{F}_{\text {tabel }}$ yaitu 3,067 > 2,78. Maka, Ho ditolak dan Ha diterima. Dengan maksud variabel Likuiditas, Pajak dan Profitabilitas mempengaruhi dengan signifikan terhadap Struktur Modal untuk Perusahaan Bidang Aneka Industri Di BEI Tahun 2015-2017.

\subsection{Pengujian Hipotesis Secara Parsial (Uji t)}

Pengujian $t$ dipakai dalam melihat sejauh mana pengaruhnya 1 variabel bebasnya secara mandiri dalam mejelaskan variabel terikatnya. Perolehan hasil pengujian uji $\mathrm{t}$ sebagai berikut : 
Diperoleh hasil uji sebagai berikut :

1. Hasil uji statistic t menunjukkan variabel likuiditas memiliki $t_{\text {hitung }}$ adalah sebanyak-2.439 dengan nilai signifikansinya 0,018 , sementara $t_{\text {tabel }}$ ialah -2.00488 dengan di bawah signifikannya 0,05 sehingga bisa disimpulkan $\mathrm{t}_{\text {hitung }}<\mathrm{t}_{\text {tabel }}$ maka hasilnya ialah Ho ditolak dan Ha diterima.

2. Variabel Pajak memiliki thitung yaitu $-0,459$ dengan nilai signifikansinya 0.648 , sementara $\mathrm{t}_{\text {tabel }}$ ialah sebesar -2.00488 dengan di atas signifikansinya 0.05 sehingga bisa disimpulkan $t_{\text {hitung }}>t_{\text {tabel }}$ maka hasilnya ialah Ho diterima.

3. Variabel Profitabilitas memiliki $t_{\text {hitung }}$ adalah sebesar 1,470 dengan nilaiinya signifikansi 0,147 , sementara $t_{\text {tabel }}$ adalah 2,00488 dengan di atas signifikansi 0.05 sehingga bisa disimpulkan thitung $<t_{\text {tabel }}$ maka hasilnya ialah Ho diterima.

\section{KESIMPULAN DAN SARAN 5.1 Kesimpulan \\ Pada hasil penelitian, dapat} disimpulkan bahwa variabel likuiditas secara parsial memberikan pengaruh negatif dan signifikan pada Struktur Modal di Perusahaan Sektor Aneka Industri di BEI tahun 2015-2017. Pajak secara parsial berpengaruh negatif dan signifikan pada Struktur Modal di Perusahaan Sektor Aneka Industri di BEI tahun 2015-2017. Profitabilitas secara parsial berpengaruh positif dan signifikan pada Struktur Modal di Perusahaan Sektor Aneka Industri di BEI tahun 2015-2017. Likuiditas, Pajak dan Profitabilitas berpengaruh signifikan pada Struktur Modal di Perusahaan Sektor Aneka Industri Di BEI tahun 2015-2017. Hasil uji koefisien determinasi didapat nilai adjusted $R$ square $\left(\mathrm{R}^{2}\right)$ 0,100 ataupun sama dengan
$10 \%$. Variabel bebas berpengaruh pada Struktur Modal di Perusahaan Bidang Aneka Industri Di BEI tahun 2015-2017 sebesar $10 \%$ dan sisanya $90 \%$ yang mempengaruhi ialah variabel lainnya misalnya Stabilitas Penjualan, Kebijakan Deviden, Struktur Aktiva.

\subsection{Saran}

Dari hasil penelitian yang sudah diteliti, berbagai saran yang bisa peneliti sampaikan, yakni sebagai berikut :

Kiranya hasil penelitiannya ini bisa digunakan peneliti selanjutnya. Pihak investor harus memperhatikan likuiditas, pajak, dan profitabilitas agar lebih berhati-hati menanamkan sahamnya karena tinggi rendahnya Likuiditas, Pajak, dan Profitabilitas sangat mempengaruhi lancarnya suatu perusahaan. Kiranya hasil penelitian ini bisa digunakan bagi mahasiswamahasiswi yang membutuhkan bahan acuan dan dapat memperkaya karya ilmiah yang berada di perpustakaan Universitas Prima Indonesia.

\section{DAFTAR PUSTAKA}

Amanda, Ayu, R. D. (2016). Pengaruh Profitabilitas, Ukuran Perusahaan, Likuiditas, dan Resiko Bisnis Terhadap Struktur Modal pada Perusahaan Property dan Real Estate: Vol. 5 No.7.

Christianti, A. (2017). PENGARUH SIZE, LIKUIDITAS, PROFITABILITAS, RISIKO BISNIS, DAN PERTUMBUHAN PENJUALAN TERHADAP STRUKTUR MODAL PADA SEKTOR INDUSTRI PROPERTI. 12(1), 12. 
Ghozali, H. I. (2016). Aplikasi Multivarate dengan Program SPSS (Edisi ke-4).

Hardanti, S., \& Gunawan, B. (2010a). PENGARUH SIZE, LIKUIDITAS, PROFITABILITAS, RISIKO, DAN PERTUMBUHAN PENJUALAN TERHADAP STRUKTUR MODAL (STUDI EMPIRIS PADA PERUSAHAAN

MANUFAKTUR DI BURSA EFEK INDONESIA). Jurnal Akuntansi dan Investasi, 18.

Irham, F. (2015). Pengantar Manajemen Keuangan (5th ed.). Bandung: Alfabeta.

Rahmadianti, M., \& Yuliandi, Y. (2020a). Pengaruh Profitabilitas, Risiko Bisnis, Kepemilikan Manajerial, Dan Pajak Terhadap Struktur Modal. Jurnal Ilmiah Akuntansi Kesatuan, 8(1), 2736.

https://doi.org/10.37641/jiakes. v8i1.288
Sugiyono. (2016). Metode Penelitian Pendidikan (Pendekatan Kuantitatif, Kualitatif dan $R \& D \quad$ (cet. 23). http;//katalogdpkblora.perpusn as.go.id/detail-opac?id-28540

Toni, A. A. (2016). FAKTOR-FAKTOR YANG MEMPENGARUHI STRUKTUR MODAL PERUSAHAAN

MANUFAKTUR DI BURSA EFEK INDONESIA. Jurnal Benefita, l(2). https://doi.org/10.22216/jbe.v1 i2.1429

Wulandari, N. P. I., \& Artini, L. G. S. (2019). PENGARUH LIKUIDITAS, NON-DEBT TAX SHIELD, UKURAN PERUSAHAAN DAN PERTUMBUHAN PENJUALAN TERHADAP STRUKTUR MODAL. EJurnal Manajemen Universitas Udayana, $\quad 8(6), \quad 3560$. https://doi.org/10.24843/EJM UNUD.2019.v08.i06.p10

www.idx.co.id 